\title{
COLÉGIO IMACULADA CONCEIÇÃO: NARRATIVAS ORAIS, INSTITUIÇÕES E PROCESSOS DE ESCOLARIZAÇÃO EM CÁCERES/MT
}

\author{
Alexandra Lima da Silva \\ ProPEd/UERJ
}

Giuslane Francisca da Silva

UFMT

\section{RESUMO}

Considerando que também a escola é um lugar de memória e de pesquisa e ressaltando a importância da preservação do patrimônio histórico e cultural, o presente artigo procura discutir os significados do Colégio Imaculada Conceição para a cidade de Cáceres/MT, a partir das narrativas orais de ex-estudantes. Objetiva dar visibilidade às diferentes memórias em torno de centenárias instituições educativas, indicando com isso, diferentes usos e significados em torno das mesmas, atentando também, para a importância da preservação desses espaços enquanto patrimônio histórico-cultural da cidade.

Palavras-chave: Memória; Instituição Educativa; História da Educação; Narrativas orais.

\section{COLÉGIO IMACULADA CONCEIÇÃO: ORAL NARRATIVES, INSTITUTIONS AND SCHOOLING PROCESSES IN CÁCERES/MT}

\begin{abstract}
Considering that also the school is a place of memory and research and emphasizing the importance of preserving the historical and cultural heritage, this article discusses the meanings of the College Immaculate Conception to the city of Cáceres/MT, as of oral narratives former students. Aims to underline the different memories around centennial educational institutions, indicating it different uses and meanings around them, paying attention also to the importance of preserving these areas as historical and cultural heritage of the city.
\end{abstract}

Keywords: Memory; Educational institution; History of Education; Oral narratives.

Muitas vezes passamos distraidamente por antigos prédios escolares e não nos damos conta do quanto expressam da fabricação de novas sensibilidades e da compreensão de que este seria o espaço privilegiado para educar as novas gerações. Parece que sempre estiveram ali. Mas, não é bem assim. Olhares atentos para as fachadas das escolas instigam a aprofundar o conhecimento sobre a importância que desempenharam na história da educação e na história da cidade. Elas trazem as marcas do tempo. Como lugares de memória, as edificações escolares se constituem em convites para investigações, o que exige driblar a ausência de fontes, a dispersão documental e o descaso com a documentação da escola. 
Desse modo, quais são as instituições educativas centenárias de Cáceres/MT? Porque estudá-las? Qual a relação entre escola, memória e cidade? Onde se encontra a documentação destas instituições na atualidade? Além dos objetos da cultura material, como podemos pesquisar as práticas educativas de tais espaços? Que sujeitos fizeram as escolas de outros tempos? O que permaneceu nestas escolas hoje? O que mudou? Por quê? Quais os usos de tais espaços na atualidade? O presente artigo procura adentrar nos corredores do Colégio Imaculada Conceição em Cáceres/MT a partir dos olhares de exestudantes dessa centenária instituição educativa.

Compreendem-se as instituições educativas também enquanto "lugares de memória" (NORA, 1993), em que "a memória é vida, sempre guardada pelos grupos vivos e em seu nome, ela está em evolução permanente, aberta à dialética da lembrança e do esquecimento, inconsciente de suas deformações sucessivas, suscetível de longas latências e súbitas revitalizações" (NORA, 1993, p. 3). Em relação às categorias de análise, dois conceitos serão cruciais: memória e patrimônio. O conceito de memória e suas diferenças em relação à história foram bem sintetizados por Jacques Le Goff:

\begin{abstract}
A memória é um elemento essencial do que se costuma chamar identidade individual e coletiva. Memória é a própria preservação da identidade coletiva e, ao mesmo tempo, instrumento e objeto de poder. Toda memória é, num momento subseqüente, história. Sua temporalidade rompe com o tempo linear para alcançar o tempo social - a lembrança é a recordação do vivido. É também um tempo revivido que tem seu momento fundamental na consciência do singular. Não é um fenômeno que se esgota no indivíduo ou que tem lugar no vazio social. A lembrança surge num contexto preciso, na relativa estabilidade de uma situação que desenvolve a vida do sujeito. A memória é seletiva, opera com o passado olhando para o futuro, dota a sociedade (incluindo aqui os grupos sociais) de coesão, conferindo-lhe sentido e deve ter visibilidade pública - os "lugares de memória" (LE GOFF, 1998, p.216).
\end{abstract}

Procuramos dialogar, deste modo, com os estudos já produzidos em torno das categorias "instituições educativas" (BUFFA \& NOSELLA, 2013; NASCIMENTO, 2007; GATTI JÚNIOR \& OLIVEIRA, 2002; MAGALHÃES, 1999). Especificamente a respeito da importância da preservação das instituições educativas centenárias, destaco o livro Outros tempos, outras escolas (MIGNOT, SILVA, SILVA, 2014), fruto das reflexões e pesquisas oriundas do documentário Tantas Escolas, Tantas Memórias (FAPERJ/2011), a respeito de escolas centenárias da cidade do Rio de Janeiro. No âmbito da linguagem cinematográfica, destaco também, o vídeo Olhares: Instituições Educativas Centenárias de Cuiabá (FAPEMAT/2015), oriundo de projeto de pesquisa financiado pela FAPEMAT (2014-2016). Por sua vez, a presença de instituições educativas católicas em Mato Grosso foi tema de estudos diversos (DOURURE, 1977; MANFROI, 1997; SCHENEIDER, 1988).

As entrevistas que servem de base para este trabalho são resultados do Projeto de Pesquisa "História, Memória e Oralidade: as narrativas da cidade de Cáceres", vinculado ao Núcleo de Documentação de História Escrita e Oral (NUDHEO/ Departamento de História/ UNEMAT/Cáceres/MT), sob a coordenação da professora Maria Socorro de Sousa Araújo. Este projeto reuniu depoimentos de pessoas residentes em Cáceres que, na época, contavam com idade acima de 60 anos e falaram de suas experiências de vida. $\mathrm{O}$ projeto foi desenvolvido entre os anos de 2005 e 2007, acompanhado por grupos de bolsistas, e possuía como principal objetivo registrar as memórias de moradores da cidade, 
com o intuito de "preservar" aspectos da cidade, tais como sociabilidades, modos de vida, costumes e etc, que não se encontram registrados em documentos oficiais.

Inicialmente era aplicado um questionário único para cada entrevistado(a), mas por se tratar de histórias de vida, frequentemente o(a) entrevistado(a) fugia da pergunta e a conversa tomava outros rumos. O critério de seleção dos entrevistados se deu essencialmente na busca de "ouvir" pessoas com maior idade, visto que um dos objetivos era reunir narrativas sobre aspectos da cidade que estavam se apagando em decorrência da passagem do tempo e não estavam registradas em documentos oficiais.

Embora os(as) entrevistados(as) não emitam com precisão a temporalidade a qual se referem em suas narrativas, ao juntarmos os elementos que expressam, aferimos que estejam se referindo aos meados da década de 1920 a meados de 1950 . Nesse momento, Cáceres/MT possuía um pequeno número de moradores e sem muitos atrativos para investidores. No âmbito educacional, possuía ainda um número inexpressivo de escolas. Tanto as escolas privadas como as públicas, atendiam apenas ensino primário, somente em 1948, foi fundado o Ginásio Onze de Março, se caracterizou como a primeira instituição educativa de segundo grau, na cidade de Cáceres/MT.

O Colégio Imaculada Conceição foi durante muito tempo (e ainda é) uma instituição voltada à formação de crianças das camadas elitizadas da cidade de Cáceres, buscando se destacar naquilo que se tinha de mais moderno no processo educacional. $\mathrm{O}$ colégio (também conhecido como CIC) surge no cenário da cidade de Cáceres em 1907, marcando a presença religiosa na educação cacerense.

As raízes dessa instituição remontam ao ano 1836 quando a Madre Emilie de Villeneuve fundou ao Sul da França a Congregação das Irmãs de Nossa Senhora da Imaculada Conceição de Castres, ou Irmãs Azuis, como também ficaram conhecidas no Brasil. As Irmãs Azuis se notabilizaram pelos seus trabalhos missionários, aos poucos a Congregação espalhou-se por muitos países, até que em 1904 a convite do arcebispo de Cuiabá, Carlos Luís d'Amour, aportam-se nessa cidade seis irmãs para assumirem a administração do Asilo Santa Rita.

Ainda no início do século XX, as Irmãs Azuis são chamadas a irem mais longe, a avançarem por caminhos novos e desconhecidos, atendendo ao pedido dos Padres Franciscanos da Terceira Ordem Regular de São Francisco (TOR), juntamente com a vontade de continuarem a missão de Emilie, fundadora da congregação, quatro irmãs lançam-se pelo rio Paraguai com destino a São Luiz de Cáceres e em $1^{\circ}$ de janeiro de 1907 , após seis dias de viagem chegam a esta cidade. Os motivos que possivelmente influenciaram as irmãs a se estabelecerem em Cáceres/MT foram o surto de febre amarela, varíola e a peste bubônica que nesse momento assolavam a região, assim como também a pobreza existente no lugar.

A fundação do Colégio Imaculada Conceição se deu aos dias três (03) de fevereiro de 1907, o advento foi muito comemorado pelos moradores de Cáceres. Rapidamente a instituição ganhou reconhecimento pela qualidade do ensino que oferecia, conforme consta nas documentações e nas entrevistas, bem como pelo caráter rígido das disciplinas impostas pelas irmãs responsáveis pelo colégio ao corpo discente da escola, como será discutido posteriormente. O colégio foi a primeira instituição de ensino particular voltada ao atendimento do público feminino. É importante assinalar que meninos e meninas só ocuparão o mesmo espaço de aprendizagem, a partir de 1989, no período anterior, embora houvessem meninos matriculados, estes não ocupavam os mesmos espaços. Haviam espaços destinados a meninas e outros para meninos.

O colégio em questão buscava promover uma educação pautada na valorização dos princípios da fé cristã, aspecto comum nas instituições escolares fundadas e/ou mantidas 
por ordens religiosas, comumente católicas, nesse caso, as Irmãs Azuis. O colégio está localizado desde a sua fundação próxima à igreja Matriz, a Praça Barão do Rio Branco e o Rio Paraguai, área central da cidade, esse local se constituía em um emaranhado de relações socioculturais em decorrência dos mais diversos transeuntes e inúmeras relações sociais tecidas nesses espaços.

O colégio possuía uma gama de normas que recaía sobre o corpo discente, como por exemplo, as(os) alunas(os) quando chegavam a escola deveriam permanecer sentados em um saguão, sem causarem barulhos ou correrias pelo pátio ou corredores da instituição. À medida que se aproximava o momento de bater o sinal anunciando a entrada para as salas de aula, as(os) mesmas(os) eram postas(os) em fileiras organizadas(os) de acordo com as séries, logo que o sinal batia a professora de cada sala se dirigia até o saguão e chamava sua turma que a acompanhava até a sala, sempre em fileiras, ritual que se repetia para entrada e saída do intervalo, e ao término da aula.

Todos os dias a diretora do colégio entrava em cada sala de aula, e de pé os alunos a saudavam "bonjour Mamer", na saída novamente de pé se despediam com "merci Mamer". Tais normas, assim como várias outras que serão apresentadas ao longo do texto, segundo a concepção das Irmãs visavam a manutenção da ordem assim como a instituição de bons modos.

\section{Narrativas orais, instituições e processos de escolarização}

A História da Educação ao investigar o processo de escolarização e as diferentes propostas pedagógicas existentes, recorreu durante muito tempo às fontes oficiais escritas e obras confeccionadas por educadores ou intelectuais eminentes de cada época (LOPES \& GALVÃO, 2005, p. 80). Conforme salientado por Diana Vidal, um movimento interessante ocorreu em finais da década de 1980, com o crescente afastamento da historiografia da educação em relação à filosofia da educação (VIDAL, 2005). A preocupação com as fontes, com pesquisas em arquivos e constituição dos acervos promoveu uma maior especialização e autonomização no campo do ensino/pesquisa em história da educação. A escrita da história da educação apropriou-se de conceitos/categorias, problematizados como operação historiográfica.

Nesse sentido, o problema das fontes é crucial para uma compreensão das culturas escolares. Diversos aspectos da escola, suas normas e práticas em outros períodos estão registrados, em sua minoria, em documentos produzidos especificamente para o mundo educacional, e muito mais em outros traços e vestígios encontrados em um universo mais amplo de fontes (LOPES \& GALVÃO, 2005). É preciso reconhecer que não há prática escolar desligada das condições materiais de sua efetivação. Assim, os objetos preservados portam pistas das múltiplas maneiras como professores e alunos constituíram inteligibilidades e suscitam a investigação sobre as diferentes formas de apropriação desses conhecimentos, "oferecendo ao pesquisador índices sobre as relações pretéritas dos sujeitos com a materialidade escolar ou sobre a formalidade das práticas escolares, e fazendo-o recordar que as situações pedagógicas se constroem muito frequentemente por formas orais de socialização" (VIDAL, 2005, p. 24).

As narrativas orais de ex-estudantes foram fundamentais para compreender os significados do Colégio Imaculada Conceição para a cidade de Cáceres. Desse modo, defende-se a relevância das narrativas orais como fontes, visto que os relatos dos habitantes que vivenciaram a dinâmica da cidade de Cáceres revelam "tempos" e "espaços" que se tornam conhecidos através do trabalho de rememoração. Daí a 
importância dos relatos de memória, pois as expressões, o valor simbólico que alguns espaços adquirem na memória coletiva da cidade, não são possíveis de serem percebidos em documentos escritos. A memória torna-se importante categoria nas análises, enquanto campo de lutas, tensões sociais e formas de dominação e legitimação de poder, uma vez que tem sido as circunstâncias quem definiu, ao longo do tempo histórico, quais memórias e quais histórias deveriam ser consideradas plausíveis (FENELLON, 2004). Muitas memórias foram esquecidas e/ou silenciadas (POLLAK, 1989) pelos "grandes temas" da historiografia que durante muito tempo julgaram desnecessário a conservação/preservação de algumas memórias.

A história oral nos auxilia como método e instrumento de pesquisa, no sentido proposto por Marieta Ferreira e Janaína Amado, pois:

a história oral, como todas as metodologias, apenas estabelece procedimentos de trabalho, tais como os diversos tipos de entrevista e as implicações de cada um deles para a pesquisa, as várias possibilidades de transcrição de depoimentos, suas vantagens e desvantagens, as diferentes maneiras de o historiador relacionar-se com seus entrevistados e as influências disso sobre o trabalho- funcionando como ponte entre a teoria e a prática. Esse é o terreno da história oral (...). Mas na nossa área, a história oral é capaz apenas de suscitar, jamais de solucionar, questões; formula as perguntas, porém não pode oferecer as respostas (FERREIRA \& AMADO, 1996, p. 14).

A história oral será vista enquanto metodologia, que remete a uma dimensão técnica e teórica, num sentido de "produzir conhecimentos históricos", e não simplesmente, "fazer um relato de vida dos outros". Mais uma vez, retomamos a preocupação com o presente, no sentido pensando por Maria Isaura Pereira Queiroz, em que:

A história oral fornece documentação para reconstruir o passado recente, pois o contemporâneo é também história. A história oral legitima a história do presente, pois a história do presente foi durante muito tempo, relegada ao passado (QUEIROZ, 1983, p.35).

Vale pensar, também a história oral como uma possibilidade de dar visibilidade às diferentes memórias construídas. Deste modo, o presente texto busca a visibilidade destas memórias marginais, no sentido de, conforme Célia Paoli, "fazer com que experiências silenciadas, suprimidas ou privatizadas da população se reencontrem com a dimensão histórica" (PAOLI, 1991, p.3).

D. Eliane Nunes, filha de comerciantes bem sucedidos de Cáceres, assinala que sua primeira escola foi o Colégio Imaculada Conceição, tendo cursado aí o curso primário, como ela mesma rememora: "a minha primeira escola foi o Colégio das Irmãs. Praticamente, desde que eu me entendi por gente, não existia outra escola era o Colégio das Irmãs, e lá eu fiquei até terminar o $4^{\circ}$ ano; daí é que eu fui pra Campo Grande; lá eu fiz o Admissão, fui pro Oswaldo Cruz e lá fiquei” (NUNES, 2006). Ficou, mas não o tempo necessário para conclusão do curso, como discutiremos posteriormente. Os relatos de D. Eliane oferecem vários elementos para se entender tanto o funcionamento do colégio aqui trabalhado, bem como permite compreender o universo escolar de acordo com a percepção das(os) alunas(os), por vezes desprezada pelos relatos oficiais. No trecho a seguir, por 
exemplo, a entrevistada traz importantes revelações sobre as normatizações que regiam a instituição:

O Colégio era bem diferente, era um prédio antigo! (...) era uma disciplina muito boa a do Colégio, muito boa. Tinha o horário de entrar, chegava, tinha um pátio muito grande, rodeado de banco, ali os alunos sentavam, tinha uma irmã sempre fazendo um trabalhinho qualquer até uma e meia (13h30min) pra bater a sinetinha pra formar fila e entrar em sala de aula, tudo dentro dos conformes; não era esse negócio de entrar correndo, cada hora entrava um, não, era na fila. Então, a minha vida foi no Colégio das Irmãs (NUNES, 2006).

Continuando em suas rememorações sobre a escola, D. Eliane enfaticamente nomeia professores, disciplinas, conteúdos, como se pode ver no trecho a seguir:

Eu me lembro bem da irmã Febronie, que era uma freira já meio de idade, mas uma professora que mexia só com os pequenos, depois tinha a irmã Isabel, de música, eu estudei piano com a irmã Maria Marcel, aí veio Irmã Carmem (...) irmã Isabel que era professora de trabalhos manuais, uma professora muito boa (NUNES, 2006).

É possível notar nesse trecho da narrativa de D. Eliane que algumas normatizações rememoradas por ela são concebidas como "necessárias", na medida em que visavam a manutenção da ordem entre o corpo discente do colégio. O que é facilmente compreensível no processo de rememoração, visto que o depoente tende a "romantizar" determinados fatos/acontecimentos, em contraposição com a demonização de outros, como se pode ver no relato acima, no qual a entrevistada define como "muito boa" as disciplinas impostas pela instituição. Possivelmente quando a mesma frequentava a escola, não possuía essa visão, e talvez até burlasse algumas normas, no entanto, agora rememorando sobre a escola, constrói uma narrativa romantizada da mesma.

Ex-aluna do colégio, D. Clarice Arruda nasceu em Cáceres e viveu toda sua infância na Rua Quinze, como faz questão de frisar, frequentou inicialmente o Colégio Imaculada Conceição, cursando o primeiro e o segundo ano ( $1^{\mathrm{a}}$ e $2^{\mathrm{a}}$ séries $)$, no terceiro ano ingressou-se no Grupo Escolar. D. Clarice rememora sobre sua primeira turma e professora que tivera, a irmã Febronie: "professora de alfabetização, que naquele tempo falava primeiro ano A, primeiro (...) $\mathrm{B}, \operatorname{logo}$ em seguida o primeiro ano, que correspondia a $1^{\mathrm{a}}$ série de agora (...) estudei lá, primeiro ano até o segundo ano, quando foi no terceiro ano mudei pro Ginásio Estadual (...)" (ARRUDA, 2005), isto é, o Grupo Escolar, como já fora apontado anteriormente. Ao que tudo indica, quando a entrevistada faz referência ao primeiro ano que antecede a primeira série, está se remetendo ao chamado jardim de infância.

No que diz respeito às normas do colégio, D. Clarice assinala que as(os) alunas(os) não poderiam em hipótese alguma levantarem-se no decorrer das aulas; segundo ela: "você tinha que sentar e não levantar; as Irmãs ainda eram mais severas sobre isso, o pátio não podia ter um papelzinho jogado que já cortava ponto de comportamento; então a gente já ficava naquela trilha" (ARRUDA, 2005). Em seus relatos D. Clarice nomeia vários professores e disciplinas que cursou durante o período em que esteve matriculada no Colégio Imaculada Conceição. $\mathrm{O}$ trecho a seguir, embora seja um pouco longo, trazem elementos que possibilitam compreender com riquezas de detalhes a relação entre 
alunas(os) e professoras(es), bem como as disciplinas que compunham a grade curricular do colégio em questão:

Eu não gostava de matemática, meu Deus do céu! Tinha a irmã Clarice que era brava demais e eu não conseguia; eu não fui assim uma aluna exemplar, mas eu tirava minhas notas o suficiente para passar; história, eu gostava daquelas matérias assim, mas matemática eu suava frio; quando fui pro tal do latim, só fui aprender latim direito quando veio meu primo Jovino que ele me ensinou aí foi uma facilidade, adorei, mas no início (...); era Natalino que era um ótimo professor, vou te contar, aquilo que você fez na prova era aquela nota, dois e meio, três, nossa pra você tirar um quatro com Natalino você suava frio; Poti Coelho era de geografia, tinha desde de um tal de quadro sinótico, todo dia tinha que tá pronto esse quadro sinótico, porque se você não apresentasse no dia que ele chamava, o dia exato de entrega . Ele falava: "coloca o quadro sinótico aqui em cima da mesa", não fez, zero. Tuteline, ótimo professor de matemática, história, física, química, excelente professor, era um professor que explicava desde o início até você descobrir a tese; estudei também com Miltom Curvo no Admissão, a gente fazia o Admissão pra poder ir pro ginásio; Murilo Curvo, quem mais? Ah, Anália Silva, professora de inglês; teve uma professora de francês casada com um Castrillon; também outro professor de francês foi um alemão; esses foram professores que a gente teve e que respeitava muito (ARRUDA, 2005).

Note que no trecho acima D. Clarice deixa explícito as disciplinas e professores que mais gostava no colégio, como por exemplo, na disciplina de matemática que teve como professora a irmã Clarice, segundo ela, não gostava, pois apresentava dificuldades para compreensão dos conteúdos; outras disciplinas eram: história, latim, geografia e matemática com o professor Poti Coelho e Tuteline respectivamente; inglês com a professora Anália Silva, e francês com uma professora que a entrevistada não cita o nome.

Como já fora assinalado em parágrafos acima, assim que D. Clarice concluiu o segundo ano, transferiu-se para o Grupo Escolar permanecendo até finalizar o curso primário. Concluído, prestou o Admissão e ingressou-se no curso de Comércio, em Campo Grande, sua turma, segundo ela foi umas das primeiras da Escola de Contabilidade Raimundo Cândido dos Reis. Antes mesmo de concluir o curso começou a trabalhar no ramo, seguindo os passos de seus pais passando a se dedicar ao comércio. Como se pode ver no relato a seguir:

terminando o ginásio, fui umas das primeiras turmas do Comércio, Escola de Contabilidade Raimundo Cândido dos Reis, formei e antes de formar, já trabalhava, primeiro trabalhei como escriturária na Casa Jaraguá; aí depois fui trabalhar com Jorge Gattass, na casa de Luiz El Chami como escriturária, e quando estava no Luiz El Chami, abriu a primeira turma da Escola de Contabilidade e eu entrei nesta turma que foi uma das coisas boas, aí comecei a estudar; quando estava perto de terminar o meu curso, fui trabalhar no escritório de contabilidade de meu cunhado Jorge Assunção de Freitas, trabalhei lá até em véspera de casar (ARRUDA, 2005).

Também filha de comerciantes de Cáceres/MT, D. Eliane Nunes teve o privilégio que poucas crianças desta cidade tiveram, no período aqui trabalhado, especialmente se 
tratando de uma mulher. Assim como D. Clarice, estudou em um dos melhores colégios da cidade, o Imaculada Conceição, posteriormente foi para Campo Grande a convite de um tio e lá realizou o exame de admissão, sendo então aprovada e ingressando-se no ensino secundário no Colégio Oswaldo Cruz, devendo-se formar ao final dos três anos do curso, em auxiliar de escritório, no entanto, por intempéries do destino, o curso não foi concluído. D. Eliane Nunes rememora sobre sua ida para Campo Grande para cursar o secundário: "Eu saí, com doze anos eu fui pra Campo Grande, eu passei três anos em Campo Grande estudando (...)" (NUNES, 2006). E continuando, relata mais detalhadamente sobre o período em que estivera fora, e posteriormente os motivos de seu retorno sem concluir o curso, três anos depois:

eu estudei no Oswaldo Cruz, que até hoje existe esse colégio, é o mesmo prédio, fizeram alguma mudança e toda vez que eu vou a Campo Grande eu vou fazer uma visitinha lá, que é ali na Praça da Feira, ali eu tirei três anos, eu devia me formar em auxiliar de escritório, mas aí entrou uma nova lei abrindo mais um ano, que era mais um ano de taquigrafia, mais não sei o quê, outras matérias, aí eu resolvi vir pra Cáceres, aí o cupido flechou e eu fiquei por aqui (NUNES, 2006).

Segundo os relatos de D. Eliane, o abandono do curso se deu, especialmente devido ao acréscimo de disciplinas na grade curricular, cuja consequência foi o prolongamento de mais dois semestres para o término do curso, que passava de três para quatro anos. Acrescenta-se a estes, o fato de que em uma das visitas à sua família em Cáceres, conhecera aquele que viria a ser seu esposo. Ela decide então ficar em Cáceres e passados alguns dias os dois resolveram engatar namoro e D. Eliane decide abandonar o curso e poucos meses depois, se casou e passou a dedicar sua vida para cuidar dos filhos e do esposo, o que segundo a mesma, foram seus grandes amores e realizações da vida. A entrevistada procura demonstrar que tal decisão partiu de si, e que não houve resistência por parte da família em aceitá-la, para tanto, ao longo da narrativa não fica claro se essa decisão foi influenciada pela família, ou se esta, em algum momento procurou dissuadi-la de tal projeto. Durante muito tempo, a entrevistada assim que voltou de Campo Grande, trabalhou para seu pai nos negócios da família.

Filho de uma das mais ilustres famílias de Cáceres, o Sr. Lúcio Morais passou por três instituições de ensino primário, os Colégios São Luiz e Imaculada Conceição e Grupo Escolar, neste último concluiu o primário. Prestado o Admissão ingressou-se em 1936 no ensino secundário no Liceu Cuiabano na capital do estado, tendo concluído o ginasial em 1940, visto que segundo o entrevistado, essa modalidade de ensino tinha a duração de cinco anos. Em 1942, a convite de um tio foi para o Rio de Janeiro, tendo cursado em Niterói a faculdade de medicina e posteriormente um curso complementar de dois anos equivalente ao curso de odontologia, área na qual atuou ao longo de sua vida, o entrevistado desempenhou também outras atividades profissionais, como farmacêutico, comerciante e parteiro. O Sr. Lúcio Morais faz as seguintes rememorações sobre a escola: "eu entrei no colégio (...) eu estudei no Colégio das Irmãs, em vinte e oito. Vinte e oito; aí, do Colégio das Irmãs, eu passei dois anos no Colégio dos Padres, vinte e nove, trinta, por aí, dois anos; aí estudei com uma professora célebre daqui, chamava Leonídia (...) eu passei dois anos lá no Colégio dos Padres, e minha mãe me tirou e fui pro colégio do Grupo, em trinta e quatro, no quarto ano. Fiz o colégio do Grupo no quarto ano" (MORAIS, 2005). 
O Sr. Lúcio rememora ainda sobre os castigos com a palmatória, utilizados principalmente quando a professora ia tomar a tabuada das(os) alunas(os), caso errassem, levavam "bolo', como era popularmente conhecido o castigo: "naquele tempo usava bolo, ela tinha um bolo com um furo e a gente fazia roda pra tabuada, e quando o sujeito errava (...) Era uma bolada! Tinha que estender a mão e receber o bolo. E doía, né!?” (MORAIS, 2005).

Narrando sobre sua vida escolar, a também ex-aluna do Colégio Imaculada Conceição, D. Joana de Albuquerque, filha de uma família abastada da cidade, traz elementos significativos sobre as normas internas que regiam a tão imponente instituição de ensino. Embora os relatos de D. Joana não especifiquem a temporalidade abarcada, no entanto, é possível conjecturar que façam referência ao final da década de 1930 e início dos anos 1940. Segue o relato:

Eu estudei sempre aí no Colégio Imaculada Conceição. Nesse tempo as freiras eram todas francesas, era uma disciplina bem rigorosa mesmo. Diariamente, era de meia, sandália preta, saia, blusinha, e no domingo o uniforme era todo branco, blusa de manga comprida e a saia; toda manhã a madre entrava pra visitar as classes e hora que ela entrava, todo mundo se levantava e "bonjour Mamer", a hora que ela saia "merci Mamer" e todo dia era isso e foi até o Admissão, naquele tempo só tinha até Admissão; eu mesmo só fiz até aí, quem podia sair, ia pra Corumbá, mas o resto era aqui mesmo. Assim que era (ALBUQUERQUE, 2006).

As narrativas de D. Joana revelam partes do cotidiano escolar e que muitas vezes não se encontram registrados nos documentos escolares. Demonstram ainda uma realidade vivida por grande parte das crianças moradoras de cidade interioranas, a interrupção dos estudos ao fim do ensino primário, na maioria das vezes por não disporem de condições financeiras de se manterem em cidades que possuíam essa modalidade de ensino. Os obstáculos à continuação do ensino, também estavam ligados ao exame de admissão. Tal exame foi instituído em 1931 com a Reforma Francisco Campo, que se constituía numa seleção para o ingresso no ensino secundário. No entanto, a instituição desse exame, trouxe uma série de problemas, tendo em vista as enormes fragilidades do ensino no país, especialmente em cidades do interior, como Cáceres, pois a falta de escolas e as enormes dificuldades para os alunos se locomoverem até estas, ocasionava na pequena quantidade de crianças em idade escolar matriculadas. Outro problema a se juntar com estes, diz respeito a pouca eficiência do ensino primário em decorrência de vários fatores, entre eles, escolas sem estruturas e falta de professores qualificados. $\mathrm{O}$ resultado da ineficiência do ensino primário era o baixo número de aprovação no Admissão, excluindo muitos do ensino secundário e consequentemente do ensino superior.

Em Mato Grosso, por exemplo, nesse período havia poucas escolas de ensino secundário, e Cáceres até 1948 não contava com nenhuma, assim, as(os) alunas(os) quando concluíam o primário, era necessário se submeterem ao Admissão que era realizado em Campo Grande (hoje no atual Mato Grosso do Sul), Cuiabá ou Corumbá, e caso fossem aprovados, deveriam se mudar para uma dessas cidades para ingressarem no secundário. Percurso esse, seguido apenas pelos filhos das elites da cidade, que possuíam condições financeiras para mantê-los fora da cidade durante o período, no caso das meninas, ainda enfrentavam a resistência da família para permitirem sua saída de casa. Tais fatores faziam do ensino secundário, requisito para o ingresso no curso superior, um privilégio para poucos. 
No caso de D. Joana Albuquerque, assim como para grande parte dos moradores da cidade, os estudos foram interrompidos no fim do primário, pois sua família não possuía condições financeiras para mantê-la em outra cidade, como esta mesma afirma: "eu mesmo só fiz até aí, quem podia sair, ia pra Corumbá, mas o resto era aqui mesmo" (ALBUQUERQUE, 2006). Sem prosseguir com os estudos, casou-se ainda jovem e dedicou-se ao longo de sua vida a pintura e aos cuidados dos filhos e do esposo. Rememorando sobre os objetivos não alcançados, ressalta: "até hoje a única coisa que eu falo, não é totalmente que eu tenho inveja, mas eu queria assim ter tido mais estudo, que eu acho tão lindo a pessoa que tem o dom da palavra, que fala bem, porque eu adoro escutar pessoas que falam bem, que tem uma cultura (...)" (ALBUQUERQUE, 2006).

Sobre o cotidiano escolar do Imaculada Conceição, reproduzo a seguir mais um trecho do relato de D. Joana de Albuquerque que traz uma gama de elementos que marcaram sua vida nos tempos da escola:

Era muito interessante, a gente gostava muito da matemática porque era a Irmã Febronie (...) então a matemática era todo mundo de mão pra trás cantando: "dois vezes um, dois, dois vezes três (...)" (risos) (...) então tinha uma gaveta que ficava do lado que a gente levava a merenda, era sempre um pão com manteiga cada uma embrulhava, punha o seu nome e botava na gaveta lá pra na hora do recreio. Não se dizia, ir ao banheiro: "Irmã quero ir na casinha" - "não está na hora, não pode ir ainda" "Irmã já estou com muita dor" - "não está, vamos ficar parados ai" (risos). E quando dava muito de doer, eu principalmente tinha pavor de fim de mundo, de inferno, porque tinha os quadros e ela fazia as lições de catecismo, porque era obrigado e tinha que comparecer à missa e levava a caderneta pra marcar, porque senão no outro dia tirava um ponto, castigava. Era tudo ali, elas eram muito rigorosas. Agora, no final do ano faziam teatros belíssimos, muito bonitos mesmo. Assim que era (ALBUQUERQUE, 2006).

O trecho acima citado possibilita compreender um pouco mais o universo escolar, como, por exemplo, as brincadeiras nas aulas de matemática, o lanche que era levado por cada aluna(o), embrulhado, tendo nomes para identificação e então guardados numa gaveta até serem consumidos no intervalo. Em um segundo momento, D. Joana narra sobre as rígidas normas do colégio, como por exemplo, o controle das idas ao banheiro, e ao que parece geralmente as solicitações das(os) alunas(os) não eram atendidas(os) prontamente, mesmo não havendo crianças fora da sala de aula. Por ser uma instituição de caráter religioso, embora o Regulamento do ensino no estado assegurasse o ensino leigo, era muito comum que colégios, entre outras instituições ligadas a algum segmento religioso, especialmente ao catolicismo, dedicarem-se ao ensino da religião em seus estabelecimentos.

No caso das mulheres é importante ressaltar que nesse período ainda prevalecia à ideia de que a mulher deveria receber uma educação voltada para o aperfeiçoamento dos seus papéis na vida adulta, ser dona de casa, esposa e mãe, para tanto, desde criança a menina era ensinada a exercer seu "papel" na sociedade. Normalmente, às meninas ensinavam-se as primeiras letras, os trabalhos com a agulha e piano. Na maioria das vezes, não havia profundidade na educação feminina, até mesmo no ensino de línguas. Cabia à mulher apenas ter acesso ao conhecimento básico e necessário para sua vida adulta (SILVA, 2015) ${ }^{1}$. 
Exemplos disso, se pode ver em várias narrativas, nas quais as entrevistadas relatam situações que também foram vividas por muitas mulheres nesse período, é a menina que frequentava a escola para buscar formação com o intuito de aperfeiçoar-se para o casamento, aprendendo a costurar, fazer bainha, cerzir, bordar, pintar, etc. Uma matriculada no curso de piano, com o objetivo de embalar os tão badalados saraus nas noites cacerenses; outra que concluiu o curso primário, mas a família não possuía recursos financeiros para mantê-la em outra cidade; a que o pai não permitiu continuar os estudos, por achar que era pretexto "para arranjar namorado" e que apenas deveria saber ler e escrever; ou aquela que "apaixonou-se" e resolveu abandonar os estudos para se casar e seguir o destino que tão breve lhe aguardava. Enfim, são vidas com histórias, percursos e desfechos diferentes, mas ao fundo, praticamente todas carregam dentro de si a angústia de não terem tido a oportunidade de prosseguirem os estudos e galgarem elevadas posições políticas, sociais, no mundo dos negócios entre tantos outros objetivos/sonhos, que não foram possíveis de serem alcançados.

No relato que transcrevo a seguir, é possível perceber essas facetas da formação feminina para o desempenho de suas habilidades na vida adulta, de acordo com os discursos machistas, contidos no currículo do Colégio Imaculada Conceição, para tanto, utilizo um trecho das narrativas de D. Eliane Nunes, quando interrogada sobre o que oferecia a disciplina Trabalhos Manuais:

Tudo. Desde pregar botão, cerzir, fazer bainha, fazer bordado cheio, todo trabalho que você possa imaginar; e fazia uma amostra, tinha um pedaço de pano mais ou menos de uns trinta centímetros por uns oitenta, ali tinha as amostras de bainha, de ponto cruz; não, ponto cruz era outra. Só era de bainha, tinha as bainhas mais lindas que você pode imaginar, perfeitas; aí tinha outra de cerzir, crivo, rechilier, tudo que você imaginar tinha ali, isso que eu acho que era uma matéria que jamais devia ter tirado do Colégio das Irmãs, porque hoje eu garanto que as moças se casam e não sabem pregar um botão, pergunta se essas daí pregam botão, chuleia, faz bainha de calça, não faz, é todo mundo (...) (NUNES, 2006).

Os relatos de D. Eliane possibilitaram uma compreensão pormenorizada no que diz respeito ao funcionamento do Colégio Imaculada Conceição. Segundo a entrevistada, a criança que frequentava a instituição passava praticamente o dia todo no colégio, na medida em que tinha aulas de manhã e tarde e no intervalo entre um período e outro, havia sempre alguma atividade para fazer, possuindo então um regime de estudo integral, conforme se pode ver no trecho a seguir:

O Colégio das Irmãs preenchia o dia todo porque você ia à aula que iniciava às 7:30h e ia até às $11: 30 \mathrm{~h}$, voltava às $13: 30 \mathrm{~h}$ e saía às $16: 30 \mathrm{~h}$, 17:00h, então era o dia todo no colégio, não tinha assim meio expediente não, era o dia todo, o dia era cheio. E ainda trazia tarefa para casa, nesse intervalo de manhã e a tarde sempre tinha uma tarefinha, sempre um problema, um verbo pra escrever, uma redação, qualquer coisa, sempre ainda tinha uma tarefinha, tinha os trabalhos manuais também que tinham tarefa, que você tinha que dar conta daquilo (...) (MEDEIROS, 2005).

O fato é que no conjunto de entrevistas aqui trabalhado, D. Eliane figura entre as poucas mulheres que tiveram acesso ao ensino secundário, que nesse momento, 
principalmente nas cidades interioranas, desprovidas de escolas secundárias, recebia um público muito mais masculinizado, visto que ainda permanecia na sociedade a ideia de que mulher deveria ser educada apenas para o casamento, o que justifica a introdução de disciplinas como Trabalhos Manuais, Piano entre outras, no currículo de escolas femininas. Tais disciplinas deveriam contribuir para o aperfeiçoamento da mulher como futura dona de casa, enquanto que a mesma disciplina voltada ao público masculino possuía por objetivo a preparação para o mundo do trabalho.

No caso do Colégio Imaculada Conceição as(os) alunas(os) eram obrigadas(os) a comparecerem na missa e fazer anotações referentes ao ensino ministrado, caso contrário, recebiam castigos no dia seguinte, entre eles, a retirada de um ponto na média bimestral. Algumas situações relacionadas às aulas de catecismo na referida escola, são um tanto cômicas, como o medo de D. Joana de ir para "o além", ou seja, o "inferno": "era o do inferno, (risos) que tinha um relógio e a irmã mostrava assim que o ponteiro virava: "sempre ficar, nunca sair" (a entrevistada emite um tom de voz que possa representar o "além"), mas aquilo eu ia pra casa morrendo de medo (risos)" (ALBUQUERQUE, 2006). Entre os pecadas mais "perigosos" apregoados nesses ensinamentos, segundo D. Joana, constam "o de faltar à missa no domingo, desobediência aos pais, aos idosos" (ALBUQUERQUE, 2006). Como é possível notar, a questão religiosa era muito forte na formação das(os) alunas(os), ao ponto de sofrerem as penas cabíveis à escola, qual seja, a diminuição da nota, isto sem mencionar a violência simbólica, ao instituir uma religião, no caso a católica, sem levar em consideração a possibilidade de alguns/algumas alunas(os) não serem católicas(os) ou mesmo não crerem na existência do Deus cristão.

$\mathrm{O}$ colégio oferecia ensino regular que funcionava sob dois regimes, internato e externato, o primeiro, geralmente era frequentando por meninas que pretendiam ou eram instigadas pela família a seguirem carreira religiosa. A instituição só atenderá ambos os sexos em um mesmo espaço somente em 1989, ficando a cargo do Colégio São Luiz mantido pelos padres franciscanos, também franceses, a instrução de crianças do sexo masculino, como já fora assinalado em outro momento da pesquisa.

As memórias das(os) ex-alunas(os) também nomeiam professores, bem como expressam as imagens que possuem destes. Imagens em geral positivas, como se pode perceber nesse trecho: "a gente gostava muito da matemática porque era a Irmã Febronie, ela que era a nossa professora, depois passaram as outras, mas era mais a Irmã Febronie" (ALBUQUERQUE, 2006).

De família humilde, D. Marta Ribeiro é a quarta de dez irmãos, foi a única que teve oportunidade de frequentar por mais tempo a escola, pois morava em Cáceres com uma tia, ao passo que seus demais irmãos e irmãs residiam com sua mãe numa fazenda nas proximidades da cidade. Ainda assim, por uma série de fatores, não foi possível concluir o primário, especialmente devido as condições financeiras da família, que na ausência do pai, enfrentavam sérias dificuldades. Casou-se contra sua vontade com um cunhado de uma de suas irmãs, e no decorrer de sua vida dedicou-se aos cuidados dos filhos. Os anos escolares de D. Marta foram vividos no Colégio Imaculada Conceição.

Quando indagada sobre o colégio que frequentara, D. Marta afirma que este era "maravilhoso! O ensino da irmã era puxado" (RIBEIRO, 2005). O termo "puxado" que aparece no relato expressa o nível das exigências do colégio sobre o corpo discente, assim se refere também a qualidade do ensino, que de acordo com as falas dos entrevistados, o colégio apresentava um conteúdo bem consistente, a instituição contava também com um corpo docente qualificado. Em tom um tanto ufanista, a entrevistada assinala que era uma das melhores alunas de sua classe, especialmente em matemática; 
eu fui uma menina muito estudiosa, era uma inteligência tão rara na matemática (...) era uma inteligência que todo o professor falava. Mas era um raciocínio danado que eu tinha pra matemática, pra operação qualquer coisa de matemática. As alunas falavam tanto que quando tinha aqueles problemas pra resolver, quando passava no quadro, já tou sabendo, quando coisa eu já dava o coisa dele já (...). Aí, ficava um me cutucando me dá, me dá cola, né? (RIBEIRO, 2005).

Em uma dessas tentativas de passar respostas para uma de suas amigas D. Marta foi vista pela professora da classe que imediatamente procurou puni-la. Esses acontecimentos, indicam o estabelecimento de laços de companheirismo amizade entre as(os) alunas(os), nesse caso, o objetivo de D. Marta era "ajudar" suas amigas a tirarem alta pontuação na disciplina. A seguir, consta um trecho do relato em que a entrevista narra sobre o episódio em que foi pega em ato "inflacionário" aos olhos da direção/coordenação do colégio:

Quando foi um dia eu fui dá uma cola pra uma colega, pra Nana Fanaia (...) Eu sei que Nana pediu cola e eu fui dá; copiei e fui dá, a Irmã viu. Ham, foi aquele falatório: pá (...) pá (...) pá (...) Irmã puxou eu daqui, puxou dali, pra pôr de Febronie castigo. Vamos nós duas, Irmã; vamos e vai nós duas (...) e não queria pôr ela, era só eu. Ah, não vou; então vou sair daqui. Ah, mas foi aquela coisa com a Irmã, viu? E não conseguiu pôr eu de castigo porque queria pôr só eu, mas ela que tava me pedindo a cola e eu queria dar (...) (RIBEIRO, 2005).

Nas narrativas é possível notar que no Colégio Imaculada Conceição utilizava-se largamente a palmatória e outros castigos, como por exemplo, colocar as crianças que infligissem alguma norma, de joelhos em caroços de milho diante da turma. Segundo D. Marta, todo sábado as alunas passavam por uma sessão de perguntas e respostas, caso errassem ou não respondessem alguma pergunta, outra colega era convidada a submetê-la as sessões de palmatória, caso recusasse ou não batesse com certa força, o castigo seria revertido sobre si, sendo aplicado pela professora responsável. Sobre isso, D. Marta traz os seguintes esclarecimentos: "Todo nós grande entrava no bolo até seis, sete e era a sabatina todo sábado. Perguntava na ponta da língua: sete vezes oito (...), seis vezes oito (...) é, num acertou, passa o bolo. Aí, com dó de passar na mão dos outros ela falava: "vem aqui, vou ensinar você passar (...) é assim que bate, viu” (RIBEIRO, 2005).

\section{Últimas considerações}

As narrativas orais possibilitam compreender os diferentes sentidos e significados que a escola adquire na vida dos sujeitos. As narrativas dos ex-estudantes apontaram para uma série de elementos presentes no cotidiano escolar do Colégio Imaculada Conceição em Cáceres/MT que até a década de 1950, quando se tem a fundação de outra instituição primária de cunho particular, a saber, o Instituto Santa Maria, se configurará como principal responsável pela formação intelectual das elites cacerense e consequentemente, ponto de partida para o secundário. 
As narrativas das(os) ex-estudantes reconstruíram e ressignificaram o passado, possibilitando conhecer e compreender o espaço escolar e as significações destes para aquelas(es) que os compõem, especialmente as(os) alunas(os), que no interior desse contexto, constituem o elemento fundamental para as dinâmicas que se estabelecem nesses espaços. Admiração, respeito, temor, carinho, são sentimentos que se misturam, e ao mesmo tempo eternizam sujeitos que há muito tempo já se foram.

Muito além de se perceber a presente instituição escolar em sua dimensão física, as narrativas possibilitaram notar o outro lado, a versão/concepção do universo escolar aos olhos daquelas(es) que geralmente são vistas(os) como espectadoras(es), e que na realidade constituem o centro/causa da existência dessas instituições, ou seja, as crianças, adolescentes e jovens, que ao longo da história foram silenciados, deixados no anonimato, especialmente as mulheres. Essas, assim como se pode perceber, foram as que menos tiveram acesso ao benefício que segundo a lei, figura como direito de todos, a saber, a educação.

Desta maneira, a memória é importante categoria, enquanto campo de lutas e tensões sociais e formas de dominação e legitimação de poder, "uma vez que tem sido o poder estabelecido quem definiu, ao longo do tempo histórico, quais memórias e quais histórias deveriam ser consideradas certas" (FENELON; MACIEL; ALMEIDA; KHOURY, 2004, p.8). Com isto, propõe-se uma reflexão sobre as lutas em torno da produção e silenciamentos de certas memórias e da cristalização de outras, analisando as instituições educativas centenárias como "lugares de memória" (NORA, 1994, p.9).

\section{Referências}

\section{Fontes orais}

ARRUDA, Clarice. (61 anos). (jun. 2005). Entrevistadora: Maria do Socorro, Cáceres/MT, 06 de junho de 2005.

ALBUQUERQUE, Joana de. (79 anos). (fev. 2006). Entrevistadora: Maria do Socorro, Cáceres/MT, 15 de fevereiro de 2006.

COSTA, Gregório. (70 anos). (abr. 2005). Entrevistadora: Maria do Socorro, Cáceres-MT, 27 de abril de 2005.

MEDEIROS, Regina. (78 anos). (out.2005). Entrevistadora: Maria do Socorro, CáceresMT, 18 de outubro de 2005.

MORAIS, Lúcio. (94 anos). (abr. 2005). Entrevistadora: Maria do Socorro, Cáceres/MT, 20 de abril de 2005.

MOREIRA, Paulo. (61 anos). (fev.2006). Entrevistadora: Maria do Socorro, Cáceres-MT, 19 de fevereiro de 2006.

NUNES, Eliane. (77 anos). (abr. 2005). Entrevistadora: Maria do Socorro, Cáceres/MT, 09 de março de 2006.

RIBEIRO, Marta. (94 anos). (ago. 2005). Entrevistadora: Maria do Socorro, Cáceres/MT, 04 de agosto de 2005. 


\section{Referências bibliográficas}

ALVES, Laci Maria Araújo. Nas trilhas do ensino: educação em Mato Grosso: 19101927. Cuiabá/MT: EdUFMT, 1998.

BUFFA, Ester; NOSELLA, Paolo. Instituições Escolares: por que e como pesquisar. 2. ed. Campinas: Alínea, 2013.

CARMO, Roney Gusmão do. Memória social do aluno-trabalhador sobre a escola noturna. 2011, 135 fls. Dissertação (Mestrado em Memória: Linguagem e Sociedade). Universidade Estadual do Sudoeste da Bahia, Vitória da Conquista, 2011.

DOURURE, João Baptista. Dom Bosco em Mato Grosso: Missão Salesiana 1894-1904. Cuiabá: Salesiana, 1977.

FENELON, Déa Ribeiro. (et al). Muitas memórias, outras histórias. SP: Olho D’Água, 2004.

FERREIRA, Marieta de Moraes \& AMADO, Janaína. Usos e abusos da História Oral. Rio de Janeiro: FGV, 1996.

GATTI JÚNIOR, Décio \& OLIVEIRA, Lucia. História das instituições educativas: um novo olhar historiográfico. In: Cadernos da Educação, Uberlândia, v. 1, n. 1, p. 73-6, jan/dez 2002.

LE GOFF, Jacques. A história nova. São Paulo, Martins Fontes, 1998.

LOPES, Eliane Marta Teixeira e GALVÃO, Ana Maria. História da Educação. Rio de Janeiro: DP\&A, 2005.

MANFROI, José. A missão salesiana e a educação em Corumbá: 1899-1996. Dissertação de Mestrado, Universidade Federal de Mato Grosso do Sul, Campo GrandeMS, 1997.

MAGALHÃES, Justino P. de. Breve apontamento para a história das instituições educativas. In: SAVIANI, D., LOMBARDI, J.C. e SANFELICE, J.L.(orgs.). História da educação: perspectivas para um intercâmbio internacional. Campinas, S.P: Autores Associados, 1999.

MIGNOT, Ana Chrystina, A SILVA, Alexandra Lima da, SILVA, Marcelo Gomes da. Outros tempos, outras escolas. Rio de Janeiro: Quartet/FAPERJ, 2014.

NASCIMENTO, Maria Isabel Moura; SANDANO, Wilson; LOMBARDI, José Claudinei; SAVIANI, Dermeval (orgs.). Instituições Escolares no Brasil: Conceito e reconstrução histórica. Campinas: Autores Associados, 2007.

NORA, Pierre. Entre Memória e História: a problemática dos lugares, In: Projeto História. São Paulo: PUC, n. 10, pp. 07-28, dezembro de 1993.

NÓVOA, António. História da Educação. Lisboa: Universidade de Lisboa, 1994. Tese de livre docência.

NUNES, Clarice. Memória e História da Educação: entre práticas e representações. In: Maria Cristina Leal; Marília Pimentel. (Org.). História e Memória da Escola Nova. Rio de Janeiro: Loyola, 2003, v. 1, p. 9-26.

PAOLI, Maria Célia. História e Cidadania: o direito ao passado. In PREFEITURA DO MUNICÍPIO DE SÃO PAULO: O direito a memória: patrimônio histórico e cidadania. DPH, São Paulo, 1991. 
POLLAK, Michael. Memória, esquecimento, silêncio. Estudos Históricos, Rio de Janeiro, vol. 2, n.3, 1989, p. 3-15. Disponível em: http://www.uel.br/cch/cdph/arqtxt/Memoria_esquecimento_silencio.pdf. Acesso em: 23 de jul. de 2015.

QUEIROZ, Maria Isaura $P$. Variações sobre a técnica de gravador no registro da informação viva. São Paulo: FFLCH, USP, 1983.

SCHENEIDER, J. L. Obra de Dom Bosco em Corumbá. In: BÁEZ, Renato (Org.). O profeta do pantanal. São Paulo: Escolas Profissionais salesianas, 1988, p. 57-61.

SILVA, Alexandra Lima da. Instituições educativas centenárias de Cuiabá: lugares de memórias, patrimônio e ensino de história (1858-2014). Projeto de Pesquisa. FAPEMAT/UFMT, 2014-2016.

SILVA, Giuslane Francisca da. Trajetórias e transformações da família nuclear no Brasil. Revista Labirinto, Porto Velho-RO, Ano XV, Vol. 22, p. 361-378. Disponível em: http://www.periodicos.unir.br/index.php/LABIRINTO/article/viewFile/1104/1437 Acesso em: 09 de nov. de 2015.

VIDAL, Diana Gonçalves. Fim do mundo do fim: avaliação, preservação e descarte documental. In. FARIA FILHO, Luciano Mendes de.(org) Arquivos, fontes e novas tecnologias: questões para a história da educação. Campinas, SP: Autores Associados; Bragança Paulista, SP: Universidade São Francisco, 2000, pp.31- 44.

VIDAL, Diana Gonçalves. Cultura e prática escolares: uma reflexão sobre documentos e arquivos escolares. In: SOUZA, Rosa F. e VALDEMARIN, Vera T. (orgs.) A cultura escolar em debate: questões conceituais, metodológicas e desafios para a pesquisa. Campinas, SP: autores Associados, 2005. Apoio: Unesp/FCLAr, p.3- 30.

XAVIER, Ana Paula da Silva. Processos educativos da infância em Cuiabá (18701890). 2012. 195 fls. Tese (Doutorado em Educação). Faculdade de Educação. Universidade Federal de Minas Gerais, Belo Horizonte, 2012.

\section{Vídeos:}

MIGNOT, Ana Chrystina, SILVA, Alexandra Lima da. Tantas escolas, tantas memórias. Documentário, FAPERJ/UERJ, 2009.

SILVA, Alexandra Lima da. Olhares: Instituições Educativas Centenárias de Cuiabá. Documentário. FAPEMAT/UFMT, 2015.

\section{Notas}

\footnotetext{
${ }^{1}$ É importante frisar que no final do século XIX e mais fortemente nesse período, no que diz respeito a atuação da mulher na sociedade, esta, passou a ser muito valorizada na profissão docente, isto por que os baixos salários e os constantes atrasos nestes, fizeram com que os homens abandonassem o magistério no ensino primário, a partir disso, foram criadas medidas para incentivar as mulheres a ingressarem na carreira do magistério, enquanto que os homens se voltava para profissões mais lucrativas. Ao mesmo tempo, a profissão docente feminino era vista como extensão papel de mãe.
}

Recebido: março-16 Aprovado: setembro-16 